\title{
Cities and sustainability: how to involve the engineers
}

\author{
L. Brazil, H. Cavalcanti \& O. Longo \\ Department of Engineering, Federal Fluminense University, Brazil
}

\begin{abstract}
This paper aims to present the process of inclusion of the theme "sustainable cities" in the Civil Engineering course at the Federal Fluminense University. This is done through a research project under the title Sustainable Cities: Identifying scenarios, actors and building participation strategies and partnerships. The main objective of the research is to help the students have an education in environmental topics and subsequently develop consciousness on urban sustainability beyond the limits of sustainability in construction. The results achieved so far show that this is being achieved. This research constitutes a challenge in that it takes place in the undertow of the demands and interests of the academic life of universities and the dominant economic rationality, particularly as regards the role reserved for cities in a globalized scenario, which is to be incurred in entrepreneurial actors. Really, it is a challenge to be overcome.
\end{abstract}

Keywords: engineering, engineers, sustainable cities.

\section{Introduction}

Building sustainable cities has become one of today's most challenging tasks, given the fact that almost half of world's population (47\%) lives in urban areas, and a considerable percentage of people live under unsustainable conditions, mainly with regard to social and environmental dimensions. Such conditions may be labeled as unsustainable, as they do not promote inclusion, prosperity, creativity, education, health, democracy, a good quality of life, and do not allow the participation of the society in all the aspects associated with public issues. In Brazil, this process has been developed since the 80s with the enactment of the Federal Constitution. Since then, several documents were signed. One of the 
most important is the Statute of the City, in view of the guidelines pertaining to urban planning. Despite these measures the situation of cities is still chaotic and may worsen, especially in inner cities. Certain large enterprises, such as petrochemistry, the harbour and roads, are causing serious impacts. As an example, there is a countryside area called São João da Barra, where a big harbour is being built. The agriculture is being devastated and it received 6,000 inhabitants in only one year. Another example is Itaborai, where a petrochemical industry is situated, but where the city doesn't have enough housing and water. The engineer has an important role in the building of the cities. So, it should also have its role in the construction of sustainability, but for many Brazilians engineers, this issue doesn't form part of their worries. The projects being developed have a component of sustainability, but they are developed by other areas and the engineers don't want to work together. To overcome this and make the engineers in the future participate in the process of building sustainable cities - apart from using recyclable materials, applying water reuse and more - we are developing a participatory research with students of the discipline of Scientific Methodology of the Civil Engineering program at the Federal Fluminense University. The difficulties, the strategies and the results obtained, are currently the object of this paper.

\section{The research: reasons, methodology and difficulties}

This paper aims to present the process of inclusion of the theme sustainable cities in the Civil Engineering that is done through a research project under the title Sustainable Cities: Identifying scenarios, actors and building participation strategies and partnerships. The main objective of the research is to help the students have an education in environmental topics and subsequently develop consciousness on urban sustainability beyond the limits of sustainability in construction. The idea of this research came from our work with the students of Scientific Methodology Applied to Engineering. During 10 years of follow guidance we conducted research in various areas, including urban issues. The topics were discussed with emphasis on technical aspects, without any reference to environmental issues. Then comes the interest in including engineering professionals in building sustainable cities effectively. Many were the questions: which are the media theorists; what are the most important issues to be discussed and which are the methodological strategies. Responses were built from our entry in HIDROUFF research group, linked to the Graduate Program in Civil Engineering and organization of the research program Environment, Sustainability and Social Responsibility. The goal is to develop knowledge about environmental issues with an emphasis on urban space, with contributions from different areas of knowledge. Engineers, Economists, Biologists and Lawyers take part. This diversity is important for building different viewpoints.

The reasons for the research were as follows:

The deepening of social problems in cities due to the consolidation of the model of global cities, according to the neoliberal ideology. 
The intensification of discussions on sustainability in urban areas, including in the Rio +20 Conference; The percentage of Brazilians who live in cities is about $85 \%$, according to latest data from the Brazilian Institute of Geography and Statistics; The importance of engineering in the construction of cities; The need to incorporate the contributions of engineering and its professionals in

Table 1: $\quad$ Summary of the strategy methodology.

\begin{tabular}{|l|l|}
\hline \multicolumn{1}{|c|}{ STEPS } & \multicolumn{1}{|c|}{ STRATEGIES } \\
\hline $\begin{array}{l}\text { Conducting exploratory research on the } \\
\text { process of urbanization in the recent } \\
\text { period }\end{array}$ & $\begin{array}{l}\text { Bibliographical research and } \\
\text { fieldwork }\end{array}$ \\
\hline $\begin{array}{l}\text { Guidance for developing students' } \\
\text { papers on infrastructure projects that } \\
\text { are being conducted in RMRJ }\end{array}$ & $\begin{array}{l}\text { Research in Methodology Scientific } \\
\text { subject }\end{array}$ \\
\hline $\begin{array}{l}\text { Discussions about the city and its } \\
\text { projects with students }\end{array}$ & Methodology Scientific subject \\
\hline Organization of research & $\begin{array}{l}\text { Meetings with researchers } \\
\text { HIDROUFF }\end{array}$ \\
\hline Construction of theoretical basis & Manu authors \\
\hline $\begin{array}{l}\text { Systematization of information about } \\
\text { the city and its insustainabilities }\end{array}$ & $\begin{array}{l}\text { The systematization was based on } \\
\text { the guidelines of the authors listed } \\
\text { above }\end{array}$ \\
\hline $\begin{array}{l}\text { Identification and analysis of } \\
\text { documents - reference that addresses } \\
\text { sustainability in urban areas in the } \\
\text { country, in the period from 1980 to } \\
\text { 2010 }\end{array}$ & Bibliographic search \\
\hline $\begin{array}{l}\text { Identification of the main actors that } \\
\text { promote sustainability in urban areas }\end{array}$ & Bibliographic search \\
\hline $\begin{array}{l}\text { Identification of students' conceptions } \\
\text { about the city and building } \\
\text { sustainability }\end{array}$ & Application survey \\
\hline Construction of new theories & $\begin{array}{l}\text { Survey of reference on } \\
\text { environmental issues at the } \\
\text { university } \\
\text { A survey on the role of the engineer } \\
\text { in society }\end{array}$ \\
\hline $\begin{array}{l}\text { Systematization of students' } \\
\text { conceptions }\end{array}$ & $\begin{array}{l}\text { Incorporation of learning in } \\
\text { environment in research disciplinary } \\
\text { practices and in curricular content }\end{array}$ \\
\hline
\end{tabular}


discussions about urban sustainability. The methodological approach is participatory research: students take part of a discipline called Scientific Methodology of Civil Engineering, Universidade Federal Fluminense. We chose this method because it can facilitate the production of environmental knowledge and the incorporation of the same, within the framework of changes. It requires a reorientation of production processes and application of knowledge, as well as training of professional skills that may lead to a transition to sustainable development. The reorientation of these processes involves the incorporation of environmental knowledge in emerging theoretical paradigms, disciplinary practices in research and curriculum of educational programs [1]. The research participant, for their methodological characteristics, can promote changes in the form of knowledge production, which in Brazilian universities has been compartmentalized and without involving undergraduates in this process. There are some research programs, but the number of participants is small. We understand the great contribution of participatory research for students' development of skills - students being both subjects and objects [2].

This research constitutes a challenge to the extent that the environmental training and awareness of male and female students on the issues of urban sustainability, beyond the limits of sustainability in construction, implies a walk in counter of the demands and interests of academic life of universities and the dominant economic rationality [1].

To these difficulties, we add the role that cities now have from the 90s: actors and entrepreneurs who need to adapt to market rules in a globalized world and become global cities. According to Maricato [3], the neoliberalism applied to cities make these instrumentalize to compete with other global cities for foreign investment. Accordingly, interventions are to be located in areas with the greatest potential for profitability, symbolic and real estate. It is the consolidation of city-commodity that must be sold and managed as a private and responsible company. This view can be seen in Brazil and it can be an obstacle to the construction of urban sustainability, in that extensive areas are not covered by the agenda of the investments and their problems have aggravated it or are created new.

\section{Brazilian cities, engineers and sustainability}

Sustainability and Engineering discussions of sustainability in engineering have been conducted since the 80s. The authors as part of this debate: a significant contribution is from Bidone and Morales [4]. The authors present an operational approach to the contributions of Engineering. Noteworthy is the approach that is made on the integration of environmental aspects in the analysis of technical and economic feasibility of policies, plans, programs and projects.

The authors assess the work to be constructed as "a contribution to an education that incorporates solidly evolution of environmental knowledge and, in this case, the very awareness of the professional to the social relevance of their work. What we can see in these publications is a use of the concept of sustainability restricted to technical and economic aspects and under 
construction. For some authors, this boils down to reusing materials, water reuse and proper disposal of the waste produced in construction sites. Evidently, the technical aspects are important and need to be incorporated in the projects of Civil Engineering, but need to be expanded in order to contribute to the sustainability of cities. This concept was created in the 90s and Brazil has several definitions:

The first of these is present in the City Statute, and became known as the Law 10.257, signed in 2000. According to the Statute, sustainable cities are those that guarantee the right to urban land, housing, environmental sanitation, the urban infrastructure, transport and public services, work and leisure, to present and future generations.

An important document is the Agenda XXI Brazil, crafted in 2002. It does not have a definition of sustainable cities, but introduces two concepts, notions considered key to the theme of sustainable cities: expanded and progressive sustainability.

The first notion conceives sustainability as a pragmatic process of sustainable development. The second introduces new dimensions, which provide an understanding beyond issues of economic and environmental sustainability and can be designed according to the specificities of each country or region. In addition to incorporating several dimensions, the document recommends the inseparability of the approach in addressing the environmental and social problems through a combination of social dynamics with the dynamics of reducing environmental impacts in urban space. Finally, we have the platform of sustainable cities that considers how sustainable those are: inclusive, prosperous, creative, education-wise, healthy and democratic - that they provide a good quality of life for citizens and allow the participation of society in all aspects of public life.

We use the recommendation of inseparability in formulating a concept of sustainable cities to be used by us. This guarantees the rights stipulated in the City Statute and the Sustainable Cities Platform, encouraging a multidisciplinary approach to urban problems.

The exploratory research on urbanization in recent years has shown us the deepening socio-environmental problem, driven by the neoliberal model of urbanization, implemented through the Strategic Plans, which allowed us to identify spatial inequalities and insustainabilities.

For an understanding of spatial inequalities one needs to organize a simple classification, consisting of 4 categories of the city:

The city center is made up of city neighborhoods located well, and icons perceived as disclosed in urban marketing. They are beginning to constitute a consumption dream for a portion of the population. Each meter of land is extremely expensive, the target of real estate capital. Every day new property developments are created and there are items introduced by differentiation. Many of the students who attend Engineering are from this city category.

Beside the icons there are some slums, which also experience growth and are occupied by a poor population, but with access to various services, especially by actions of NGOs. The city of neighborhoods - are the neighborhoods adjacent to 
downtown areas that have good services and equipment and are occupied by a lower middle class. Some of these areas are undergoing renovation and internally differentiate themselves by creating prime areas. They also have slums, nearly all of ancient occupation.

The inner cities - cities are located outside of the metropolitan area. Some cities are grouped into mesoregions The cities of the periphery - are the areas occupied in the 70s as a result of removal of slums. The greatest expressions are the West Zone, Fluminense and São Gonçalo.

The risk-city - Most are located on the fringes of neighborhoods, but may also be in central neighborhoods, suburbs or countryside. Its main feature is the location in hazardous areas: hillsides, riverbanks, roadsides, dumpsters disabled or enabled. The mountainous region has some of these cities. Central or peripheral; all feature a series of insustainabilities. We used the dimensions of sustainability developed in the midst of Agenda XXI, used by authors like Sachs [5].

Environmental Sustainability: It concerns the carrying capacity of the associated ecosystems to absorb or recover from attacks derived from human action. Implying a balance between emission rates and/or waste production and absorption rates and/or regeneration of the base natural resources. Ecological sustainability: Refers to the physical basis of the growth process and aims at the conservation and rational use of natural resources inventory incorporated into productive activities. Cultural sustainability - can be understood as the need to maintain the diversity of cultures and values, practices on the planet, the country and/or region and integrating over time the identities of the people. Social sustainability - is related to the promotion of improved quality of life and reducing levels of social exclusion through public policies of redistributive justice.

Sustainability policy - refers to the construction of full citizenship of individuals by strengthening democratic mechanisms of formulation and implementation of public policies on a global scale, thus concerns government and governance at local, national and global levels;

Institutional sustainability - means the need to create and strengthen institutional engineering and/or institutional apparatus through design and by taking into account sustainability criteria. These sustainabilities are not present in Brazilian cities, nor in cities of other countries. This was one of the most prominent themes in official discussions of the Rio +20 , the result of the recommendations of UN HABITAT. It was also discussed at the World Urban Forum, held in Italy in 2012. Scholars of urban issues in Brazil point to the possibility of deepening social problems, caused by the consolidation of the model of urbanization, according to neoliberal ideas. This model is realized through: a) creation of global cities, so they become commodities that can be offered in the global market for large events, b) incorporation of the inner cities to the global marketplace, by conducting large projects, c) construction of real estate megaprojects.

This possibility can be observed by the refurbishment of Rio de Janeiro from the time that the city applied to host the 2016 Olympics. It can also be seen in 
cities like São João da Barra, a city that will be home to the Port of Acu and Itaboraí that hosts a petrochemical complex. The realization of these projects may have serious impacts on urban sustainability, committing inclusion, prosperity, creativity, potential for education, health, quality of life and participation of society in all aspects of public life. One possibility to minimize these impacts is the item we add to the definition of sustainable cities, which is a multidisciplinary approach to urban problems.

\section{The merger of knowledge in disciplinary practices environmental research and curriculum content}

We consider a multidisciplinary approach not only conducting a search on a particular topic, but more in specific, the participation of several professionals. For us it means the inclusion of themes, which in this case is the urban, permanently in the process of training professionals, disciplinary practices through research and curriculum, so that beyond the technical vision there will be also a broader and progressive view. In this process it is necessary that engineers:

a) are able to understand their role as builders of the city, in a class society, whose differences materialize in concrete and urban areas;

b) know the city's many faces and know that these are the result of an urbanization model, based on exclusion and spatial segregation;

c) understand urban sustainability in its various dimensions

d) have information about the legal instruments and participatory design of cities

e) make uncomfortable reading for environmental projects in progress

f) build forms of participation in construction engineering of urban sustainability.

This script has been developed along with students enrolled in courses of Scientific Methodology Applied to the Technical Engineering and Construction. The first is offered in the second semester and the second in the eighth. During the year 2012, we operate with about 320 students and 5 teachers. In 2013 we will expand the work to other disciplines.

\section{Conclusions}

In the course of 2012, we discussed with students the role of the engineer in a class society, as is the Brazilian, whose major manifestation can be seen in the segregated city. Do not intend to turn students into concerned urban activists, but help to understand they need to have a political stance. For many students the city is divided into two spaces: formal and informal and are just unsustainable environmentally and ecologically. We seek to expand their gaze on the city, in order to identify the multiple cities that are built, as byproducts of global cities.

Many students live in cities and do not have product information about the product. So show them, through discussions and future visits, insustainabilities in 
the various forms of such sites. Currently we have several byproducts. Most worrisome are the risk-cities. In them, there are environmental and ecological risks, largely due to climatic factors: floods, landslides, but are intensified by the precarious dwellings. There are also social risks, such as homicide, robbery, hunger, trafficking, among others. After our work, students come to understand that these aspects need to be included in urban sustainability.

In both groups, the legal instruments that guarantee the right to sustainable cities have been presented. One of the most important ones is the City Statute. This law is known by most students. So we promoted a thorough study of it. Thus, students are realizing

Reading of environmental projects can be considered as one of the most interesting points of our work, in order for students to expand their views. We chose three projects to work on with students: COMPERJ, a petrochemical complex being installed in Region Itaboraí, Rio de Janeiro.

Port of Acu Improvements in the city of Rio de Janeiro for the World Cup and the Olympics The reflections within the research group HIDROUFF, discussions with students and teachers show that contributions of engineering professionals can give through discussion within the projects in which they operate. They need to question the social, ecological, cultural and other aspects. They can also contribute to the implementation of projects of social and environmental responsibility in the companies where they work. It is worth noting that many of the employees are from the construction of cities byproduct. Anyway there are several possibilities that need to be identified and put into practice.

At the beginning of this paper we stressed that this research constitutes a challenge in that it takes place in the undertow of the demands and interests of the academic life of universities and the dominant economic rationality, particularly as regards the role reserved for cities in a globalized scenario, which is to be incurred in entrepreneurial actors. It is a challenge to be overcome; the results achieved so far show that this is being achieved.

\section{References}

[1] Le Boterff, G. (2003). Desenvolvendo a competência dos profissionais. Artmed.

[2] Brandão C.R. (1990). Pesquisar-participar. In: Pesquisa participante. São Paulo: Brasiliense.

[3] Maricato, E. (2000). A cidade dos pensamentos únicos: desmanchando consensos. Petrópolis: Vozes.

[4] Bidone E.D. and Morales P.R.D. (2004). Introdução ao conceito de desenvolvimento sustentavel. In: Desenvolvimento sustentavel e engenharia. Rio de Janeiro: Fundação Ricardo Franco.

[5] Sachs, I. (2008). Desenvolvimento includente, sustentável sustentado. Rio de Janeiro: Garamond. 